\title{
Epoxy putty external skeletal fixation in a tibiotarsal fracture of a wild choroy parakeet (Enicognathus leptorhynchus)
}

\author{
[Fixação externa com massa epóxi em uma fratura tibiotársica de um periquito \\ choroy selvage (Enicognathus leptorhynchus)]

$$
\text { J. I. Arias }{ }^{1} \text {, C. Beato }{ }^{1} \text {, A. Espinoza }{ }^{2}
$$ \\ ${ }^{1}$ Faculty of Veterinary and Animal Sciences, University of Chile - Santiago. Chile \\ ${ }^{2}$ Centre for Wildlife Rehabilitation (CEREFAS) - Universidad Austral de Chile - Campus Isla Teja - Valdivia, Chile
}

\begin{abstract}
Tibiotarsal fractures are common in birds because in most birds this is the longest, most exposed bone in the leg. Transverse fractures are most common and rotational and shear forces must be stabilized in order to achieve good bone regeneration. A $230 \mathrm{~g}$ male Slender-billed Parakeet or Choroy parakeet (Enicognathus leptorhynchus), with more than five years of age, was received with non-weight bearing lameness with 24 hours duration. X-rays were taken, and these revealed a closed, complete, noncomminuted transverse fracture of the distal diaphysis of the left tibiotarsal bone. Fixation was planned with 10-minute fast-setting epoxy putty. In order to assess the temperature of polymerization of the epoxy dough and the possibility of heat-bone necrosis, the temperature was recorded every 30 seconds for 12 minutes with three different amounts of the epoxy material in an ex vivo test. The temperature of the pieces reached a peak of $50-60^{\circ} \mathrm{C}$, where the highest peak corresponds to the highest amount of material. When approximately $6 \mathrm{~g}$ of putty were used, the peak temperature reached only $51^{\circ} \mathrm{C}$. This peak changed to $58^{\circ} \mathrm{C}$ when 4 times more epoxy was mixed and measured. If the temperature of the pins inserted in the bone exceeds $70^{\circ} \mathrm{C}$, bone necrosis could occur. In light of these results, the fracture was treated with $6 \mathrm{~g}$ of epoxy putty that was allowed to polymerize over a 1 A $2 / 2$ external skeletal fixation, with 1-mm pins bent at $90^{\circ}$ and joined together with cerclage wire. At 6 weeks after surgery the bird had formed a good primary bone callus, and the external fixators were therefore removed. With this approach a satisfactory recovery of the patient was achieved with normal use of the affected limb.
\end{abstract}

Keywords: parakeet, epoxy putty, external skeletal fixation, tibiotarsal fracture

\section{RESUMO}

Fraturas tibiotársicas são comuns em aves, pois, na maioria das aves, o tibiotarso é o osso mais longo e exposto nesses animais. Fraturas transversais são mais comuns, sendo que as forças de rotação e cisalhamento devem ser estabilizadas de modo a alcançar uma boa regeneração óssea. Um periquito macho do tipo psitacídeo de 230g, com mais de 5 anos, foi recebido apresentando claudicação a 24 horas não devido a transferência de carga. Os exames radiográficos revelaram uma fratura fechada completa, não triturada, transversal de diáfise distal do osso esquerdo tibiotársico. A fixação foi feita com massa epóxi de endurecimento rápido (10 minutos). A fim de avaliar a temperatura de polimerização da massa epóxi e a possibilidade de necrose desses ossos, a temperatura foi registrada a cada 30 segundos durante 12 minutos, com três quantidades diferentes de epóxi em teste in vivo. A temperatura das amostras fragmentadas atingiu um pico de 50-60 $\mathrm{C}$, em que o pico mais elevado corresponde à maior quantidade de massa epóxi. Quando foram utilizados cerca de $6 g$ de massa de vidraceiro, o pico de temperatura foi de apenas $51^{\circ} \mathrm{C}$. Esse pico foi alterado para $58^{\circ} \mathrm{C}$ quando se aumentou a quantidade de massa epóxi quatro vezes. Se a temperatura dos pinos inseridos no osso for superior $a 70^{\circ} \mathrm{C}$, pode ocorrer necrose do osso. À luz desses resultados, a fratura foi tratada com $6 \mathrm{~g}$ de massa epóxi deixada polimerizar sobre uma fixação externa, em configurações 1 A 2/2 usando pinos de

Recebido em 17 de março de 2014

Aceito em 20 de outubro de 2014

E-mail: joarias@uchile.cl 
Imm, dobrados em $90^{\circ}$ e unidos com fios de cerclage. Após 6 semanas da cirurgia, o pássaro tinha formado um calo ósseo primário, sendo os fixadores externos removidos. Com essa abordagem, concluise que houve a restauração das funções normais do membro e total recuperação da ave.

\section{Palavras-chave: periquito, massa epóxi, fixação externa, fratura tibiotársica}

\section{INTRODUCTION}

Free-range wildlife birds may suffer traumatic injuries when venturing into urban territories. This makes proper treatment and rehabilitation ethically and medically desirable before injured birds are released into their home ranges. Their management must take into consideration some special characteristics of avian bone architecture. Bird bones have thinner cortices and are more brittle than mammalian bones (Tully, 2002). Therefore, avian bones are more likely to shatter during surgery. Avian bones lack haversian systems, and the medullary cavity is crossed with bony struts that play an important role in the overall strength of the bone (Tully, 2002). Endosteal blood supply and callus formation are particularly important for avian fracture healing (Bush et al., 1976). This has important implications if intramedullary implants are to be used (Bush et al., 1976). It has also been described that the amount of time needed for an avian fracture to heal decreases proportionally to the amount of immobilization obtained at the fracture site (Newton and Zeitlin, 1977).

The use of external skeletal fixation has been widely reported for treatment of bone fractures in birds, and the types of fracture for which this approach is suitable together with the techniques used have been described extensively (Alievi $e t$ al., 2001; Orosz, 2002). However, in birds, the weight of the external skeletal fixator structure can be a limiting factor. Pet birds generally weigh less than $1 \mathrm{~kg}$, and most commercial systems work with clamps that can be too heavy or may not be compatible with the small pins $(\leq 1 \mathrm{~mm})$ which are used in birds. To reduce the weight, free-form fixation has been applied with polymethylmethacrylate (PMMA) (Hatt et al., 2007) or epoxy putty (MacCoy, 1992) often used as a custom-made connecting bar.

PMMA alone provides only a small area of contact between the cement and the smooth pin surface and may result in instability. Several methods have been proposed to increase the area of contact, including the use of pins with a roughened surface, bending the exposed ends of the pins at $90^{\circ}$, or connecting the pins to a transverse pin with cerclage wire before the PMMA is applied. (Kavanagh, 1997) Compared to PMMA, epoxy putty has shown a tendency to diminish inflammatory tissue reaction over time when used in direct contact with live tissue. Also, epoxy putty was found to be comparable to methacrylate when evaluated mechanically, with a stiffer elastic modulus for an epoxy-connected fixator (Roe and Keo, 1997). Because both polymers show an increase in temperature during the polymerization reaction, the danger of heatrelated bone necrosis must be taken into consideration when the temperature of the pins exceeds $70^{\circ} \mathrm{C}$ (Fukushima et al., 2002). This is especially true with PMMA that yields maximum PMMA surface temperatures that range from 101 to $110^{\circ} \mathrm{C}$ with a 2 -minute plateau of $>100^{\circ} \mathrm{C}$. (Preininger et al., 2012)

\section{APPROACH}

In this case report we tested the exothermic peak of epoxy putty polymerization and show for the first time the use of fast-setting epoxy putty to achieve a 1A $2 / 2$ external skeletal fixation with $90^{\circ}$ bent $1-\mathrm{mm}$ pins joined together with cerclage wire to treat a tibiotarsal fracture in a wild Slender-billed Parakeet (Enicognathus leptorhynchus).

Previous to treating the patient with external skeletal fixation, the temperature of polymerization of the epoxy putty Poxilina ${ }^{\circledR}$ (Poxilina ${ }^{\circledR}$, Akapol S.A., Calle $65 \# 6920$, Villa Ballester zip code B1563, Buenos Aires, Argentina) was tested with three different amounts of the material (approximately 6, 11, and $27 \mathrm{~g}$ ). After the pieces of epoxy were cut, they were hand kneaded for about one minute, as recommended by the manufacturer, until a uniform gray colored dough was observed. A round ball was then formed, and the probe of a digital thermometer (Thermistor HI 93503, HANNA INSTRUMENTS S.L., Polígono industrial Azitain, Parcela 3B, Apartado 379, 20600 Eibar ,Guipúzcoa, España), with an 
accuracy of $\pm 0.4^{\circ} \mathrm{C}$, was introduced radially until approximately the center of the sphere was reached. Temperature was recorded every 30 seconds for 12 minutes. The temperature of the pieces reached a peak of $50-60^{\circ} \mathrm{C}$, where the highest peak corresponds to the highest amount of material. When approximately $6 \mathrm{~g}$ of putty was assessed, the peak temperature reached only $51^{\circ} \mathrm{C}$. This peak changed to $58^{\circ} \mathrm{C}$ when 4 times more epoxy was mixed and assessed (Figure 1).

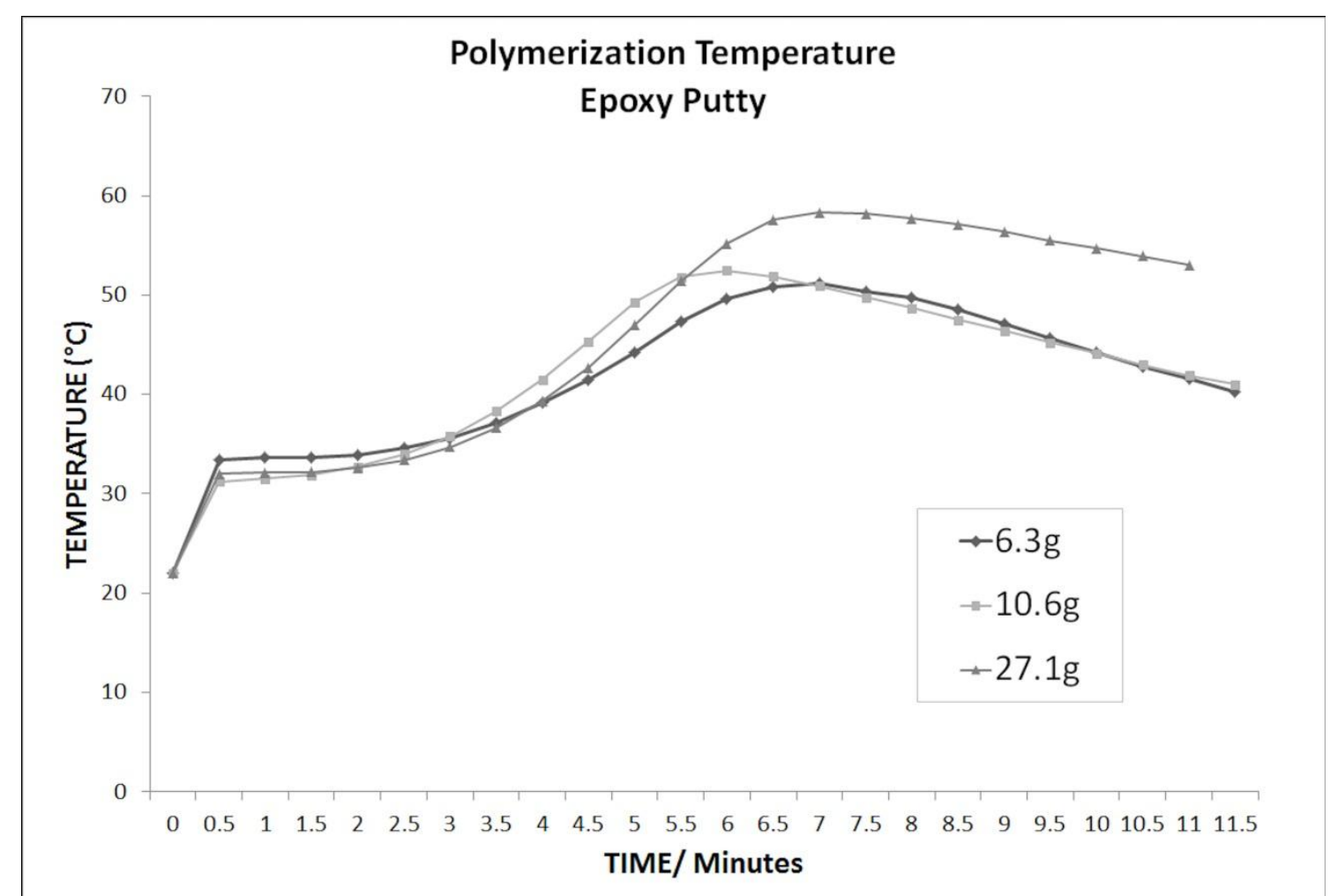

Figure 1. Temperature curve of polymerization of the epoxy putty Poxilina ${ }^{\circledR}$ (Akapol S.A., Argentina).

With these results in mind, a 230 -g, male Slender-billed Parakeet or Choroy parakeet (Enicognathus leptorhynchus), with over 5 years of age was received with 24 hour non-weight bearing lameness and was surgically treated.

This parakeet is endemic to the lower elevations of central and south Chile. It is especially dependent on seeds of the Araucaria trees during the autumn, for which its bill may be specially adapted, but in general feeds on sprouts, berries, grass, and thistle seeds. It is very similar to its sister species, the Austral Parakeet, with which it overlaps in central Chile, but is larger and much chunkier with a longer upper mandible.

Upon examination, the bird presented nonweight-bearing lameness of its left leg. Clinical examination showed misalignment in the tibiotarsal area. A fracture was diagnosed and further investigation advised.

Digital radiographic (Uno®, Cuattro Veterinary USA, 3760 Rocky Mountain Ave Loveland, CO 80538 USA), examination from ventro-dorsal and medio-lateral views confirmed a closed, complete, non-comminuted transverse fracture of the distal diaphysis of the left tibiotarsal bone (Figure 2).

The bird was induced in an isoflurane inhalation chamber, and then a small mask was used to maintain anesthesia. The surgical procedure was done under sterile conditions with the feathers removed from the zone and skin disinfection done with $2 \%$ chlorhexidine gluconate. 


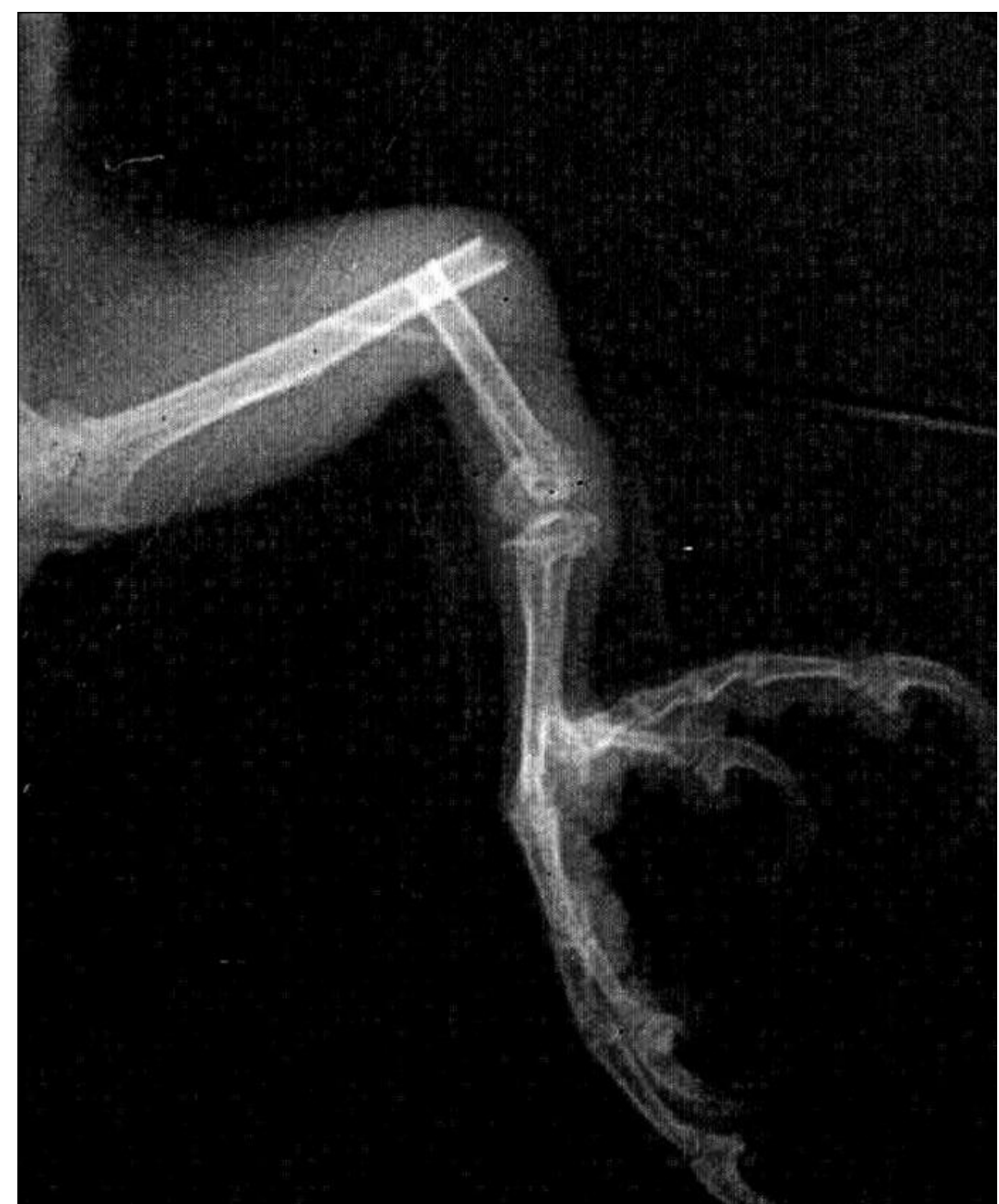

Figure 2. Parakeet. Radiographic medio-lateral examination of the left tibiotarsal bone. The view confirms a closed, complete, non-comminuted transverse fracture of the distal diaphysis of the left tibiotarsal bone.

Slow-speed predrilling was done with a twist bit followed by manual insertion of 1 -mm trocar point pins in a $60-70^{\circ}$ angle design to obtain a 1A $2 / 2$ external fixation. This technique was used because it has been shown to result in greater holding power as measured by the axial force required to extract the pin from the bone (Degernes et al., 1998). The pins were then bent to $90^{\circ}$ angles to form the connecting bar of the external fixation, and the pins were secured in place with tight cerclage wire. The fracture was in this manner aligned using a close fracture management technique.

Epoxy putty was used to fabricate a custommade connecting bar. Before applying the epoxy putty, bone alignment was assessed with digital $\mathrm{X}$-rays (Figure 3).

Approximately 5 to $6 \mathrm{~g}$ of the putty were amassed, as recommended by the manufacturer, until the two components formed homogeneous gray dough. The mixed putty was then applied over the external fixation bar and allowed to harden for 10 minutes with the bird still under inhalatory anesthesia.

Anesthetic recovery was smooth and uneventful with a total anesthetic time of no more than 45 minutes. The patient was then given cage rest with a bird recovery collar. 


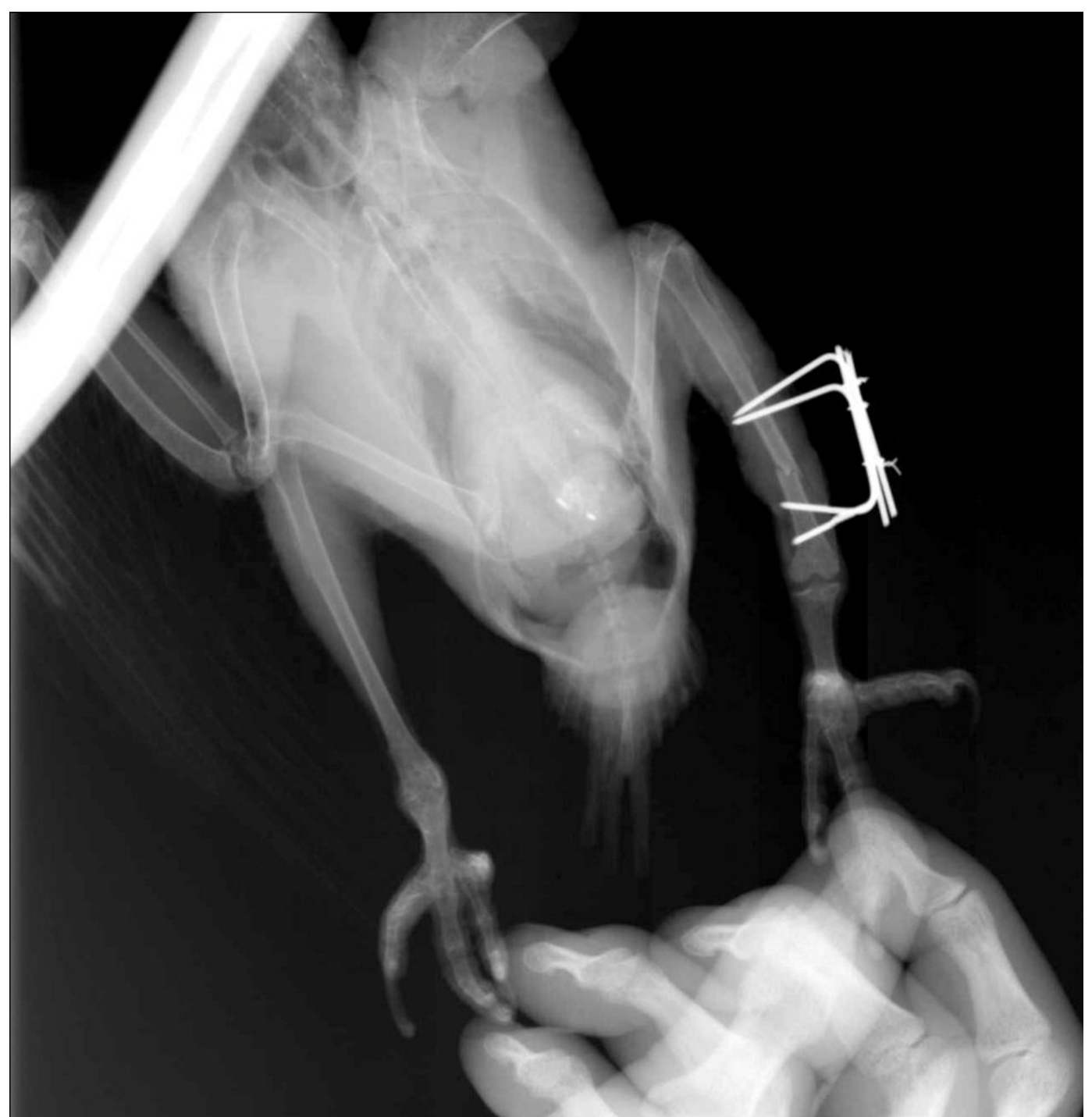

Figure 3. Parakeet. Radiographs showing bone alignment before applying the epoxy putty.

The second day after surgery the parakeet started to bear weight on the affected leg and was observed to firmly hold the rest perch with its claw. Supervised exercise on a non-slippery surface was recommended for the whole recuperation period.

After 4 weeks of cage rest, a new set of digital radiographs was taken in ventro-dorsal and medio-lateral views. To achieve this with minimal stress inhalatory anesthesia was again induced in a chamber. At this point a callus was present with osseous union evident. Fixation was not removed because it was decided that more primary callus bone density was needed (Figure 4).

In light of these results 2 more weeks of recovery were advised to complete the stability of the primary bone callus. At 6 weeks after surgery the bird was anesthetized again with the same procedure, digital X-rays were taken and analyzed (Figure 5). With this result a decision was made to remove the external fixators. Clinically, after anesthesia recovery, the bird had full use of the limb. 
Arias et al.

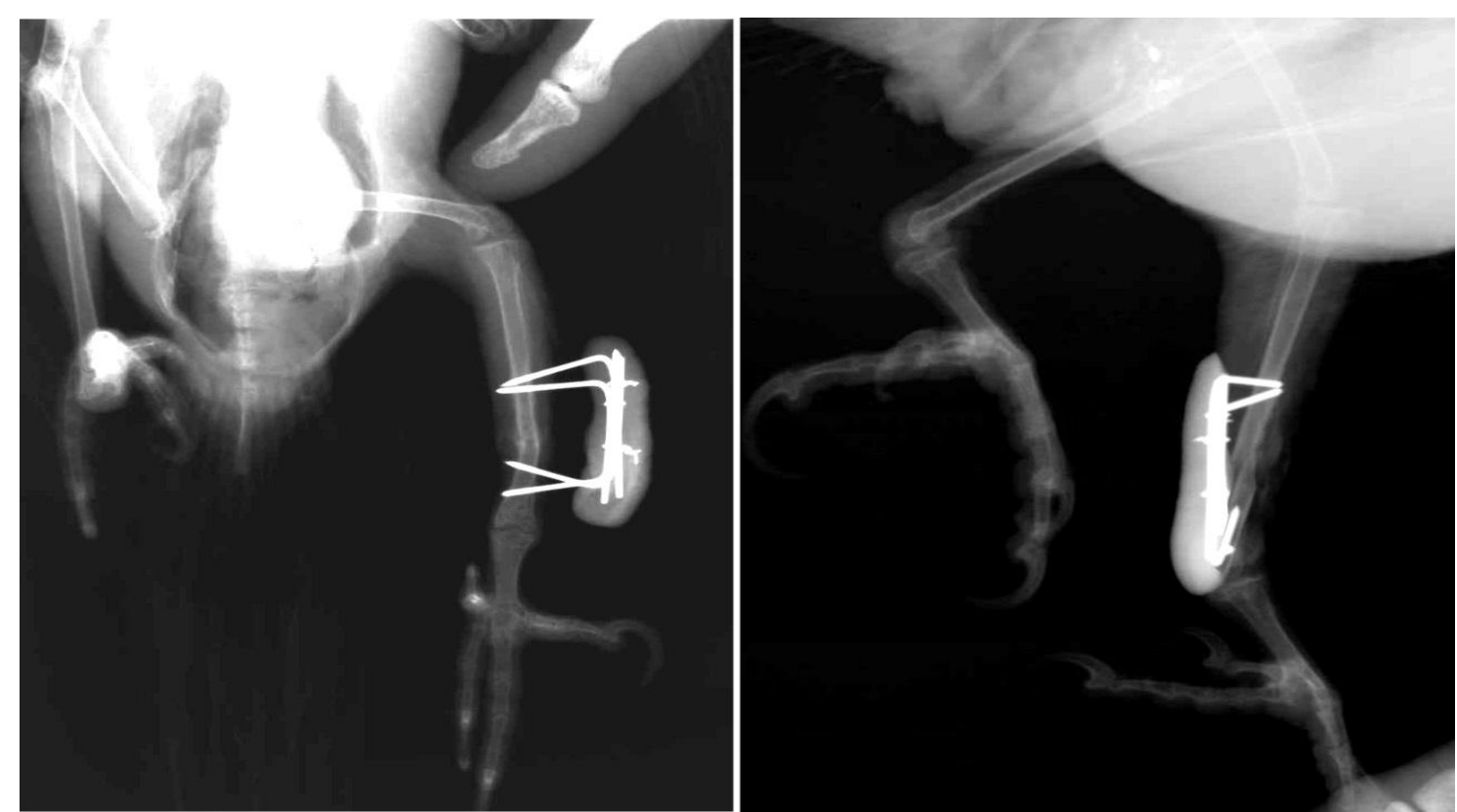

Figure 4. Parakeet. Ventro-dorsal (left) and medio-lateral (right) radiographic views taken 4 weeks of cage rest after surgery showing an initial callus with osseous union.

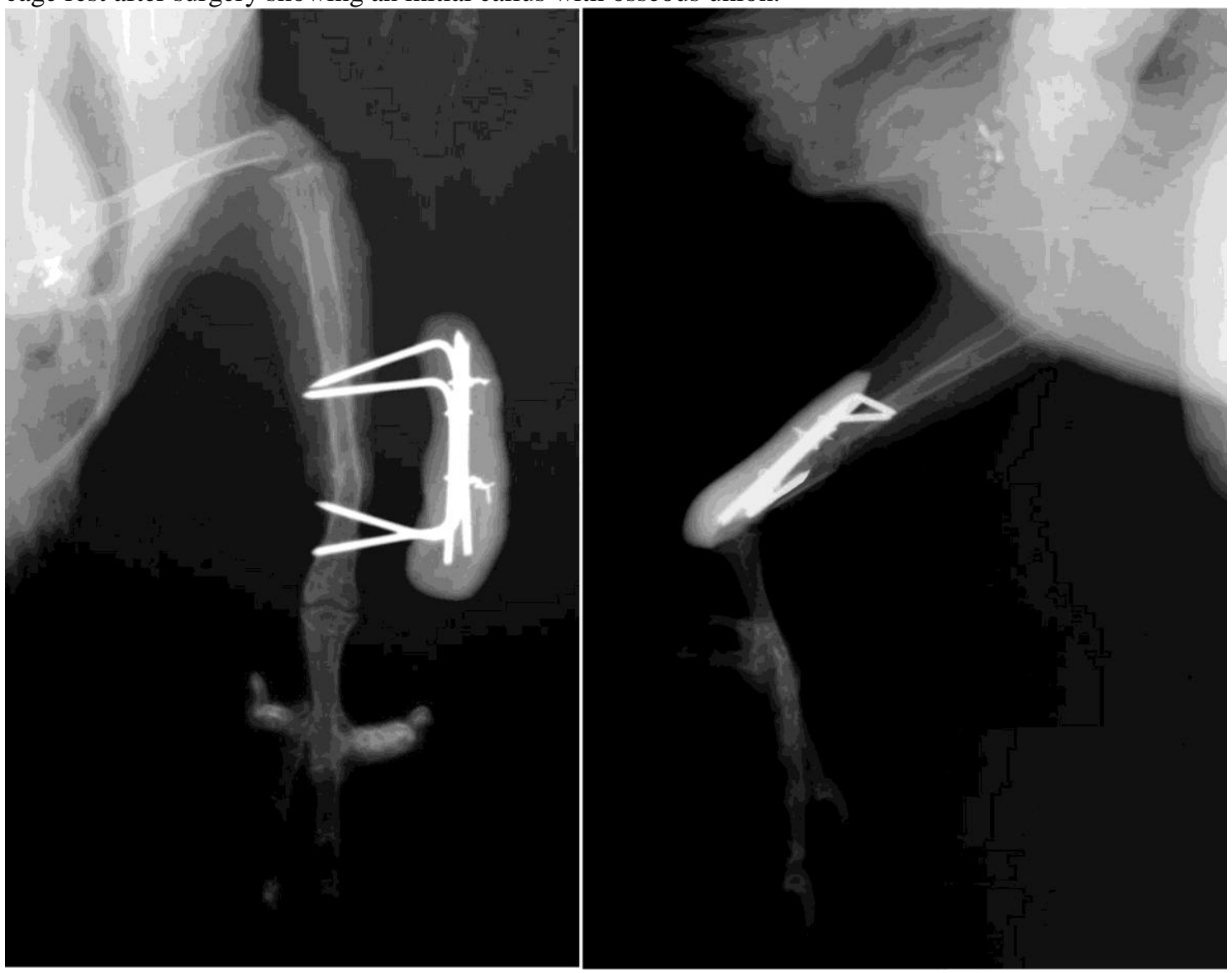

Figure 5. Parakeet. Ventro-dorsal (left) and medio-lateral (right) radiographic views taken 6 weeks after surgery with cage rest, showing a mature and well organized callus. 
Two weeks after the removal of the external fixators, the parakeet was released into the wild.

\section{DISCUSSION AND CONCLUSIONS}

Because distal limb fractures in birds are especially prone to rotation, simple casts will not oppose these forces and would also be subject to damage by the parakeet's powerful beak, which is capable of destroying most materials. Internal fixation pinning is well described, but it will not counteract rotation at the fracture site and it also destroys, at least temporarily, the intramedullary blood supply, thus preventing endosteal callus formation. In addition, internal fixation of avian long bones is complicated because of their thin, brittle cortex, which holds implants poorly and often shatters during this type of fixation (Kuzma and Hunter, 1989). This is particularly true when pneumatic bones are involved. Titanium microplates have also been described to be used to reduce avian fractures of long bones with relative success, especially depending of the differences in configuration of how they are applied (Gouvêa et al., 2011).

Epoxy putties used in free-form fixation are suitable to be used in birds because it has similar strength and greater apparent Young modulus compared to PMMA (Roe and Keo, 1997). Both PMMA and Epoxy polymers show an increase in temperature when the polymerization reaction occurs. Therefore, the danger of heat bone necrosis is an important consideration for the choice of polymer. If the temperature of the pins exceeds $70^{\circ} \mathrm{C}$, bone necrosis can occur (Fukushima et al., 2002; Alievi et al., 2008). This is especially true for PMMA, which yields maximum PMMA-surface temperatures that have ranged from 101 to $110^{\circ} \mathrm{C}$ with a twominute plateau of $>100^{\circ} \mathrm{C}$ (Preininger et al., 2012). We showed that epoxy putty reached half of the PMMA peak temperatures, making it a more secure choice when bone fixation is needed, without the need of continuous application of saline solution at the site of surgery to achieve rapid heat dissipation as described elsewhere (Alievi et al., 2008). Finally, $90^{\circ}$ bent $1-\mathrm{mm}$ pins joined together with cerclage wire were found to be a good way to strengthen the external fixation and provided a good framework for the solidification of the epoxy putty. This allowed satisfactory recovery of the patient and led to normal use of the affected limb.

\section{ACKNOWLEDGMENTS}

Special thanks to Dr. Karina Ramírez for her assistance in the anesthetic procedures.

\section{REFERENCES}

ALIEVI, M.M.; SCHOSSLER, J.E.W.; HIPPLER, R.A. et al. Redução fechada e fixação esquelética externa tipo II para o tratamento de fraturas de tibiotarso em pombos domésticos (Columba livia). Cienc. Rural, v.31, p.1019-1025, 2001.

ALIEVI, M.M.; OLIVEIRA, A.N.C.; FERREIRA, P.A. et al. Osteossíntese de úmero em pombos domésticos (Columba livia) associando-se pinos metálicos e polimetilmetacrilato intramedulares após osteotomia diafisária. Arq. Bras. Med. Vet. Zootec., v.60, p.843-850, 2008.

BUSH, M.; MONTALI, R.I.; NOVAK, R.G.; JAMES, F.A. The healing of avian fractures. A histological xeroradiographic study. J. Am. Anim. Hosp. Assoc., v.12, p.768-773, 1976.

DEGERNES, L.A.; ROE, S.C.; ABRAMS, C.F.JR. Holding power of different pin designs and pin insertion methods in avian cortical bone. Vet. Surg., v.27, p.301-306, 1998.

FUKUSHIMA, H.; HASHIMOTO, Y.; YOSHIYA, S. et al. Conduction analysis of cement interface temperature in total knee arthroplasty. Kobe. J. Med. Sci., v.48, p.63-72, 2002.

GOUVÊA, A.S.; ALIEVI, M.M.; NORIEGA, V. et al. Microplacas de titânio em fraturas de tibiotarso em pombos domésticos. Ciênc. Rural, v.41, p.476-482, 2011.

HATT, J.M.; CHRISTEN, C.; SANDMEIER, P. Clinical application of an external fixator in the repair of bone fractures in 28 birds. Vet. Rec., v.160, p.188-194, 2007.

KAVANAGH, M. Tibiotarsal fracture repair in a scarlet macaw using external skeletal fixation. $J$. Small Anim. Pract., v.38, p.296-298, 1997.

KUZMA, A.B.; HUNTER, B. Osteotomy and derotation of the humerus in a turkey vulture using intramedullary polymethylmethacrylate and bone plate fixation. Can. Vet. J., v.30, p.900$901,1989$. 
MACCOY, D.M. Treatment of fractures in avian species. Vet. Clin. N. Am.-Small, v.22, p.225238, 1992.

NEWTON, C.D.; ZEITLIN, S. Avian fracture healing. J. Am. Vet. Med. Assoc., v.170, p.620$625,1977$.

OROSZ, S.E. Clinical considerations of the thoracic limb. Vet. Clin. North. Am. Exot. Anim. Pract., v.5, p.31-48, 2002.

PREININGER, B.; MATZIOLIS, G.; PFITZNER, T. et al. In situ tele-thermographic measurements during PMMA spacer augmentation in temporary arthrodesis after periprosthetic knee joint infection. Technol. Health Care, v.20, p.337-341, 2012.

ROE, S.C.; KEO, T. Epoxy putty for free-form external skeletal fixators. Vet. Surg., v.26, p.472477, 1997.

TULLY, T.N.JR. Basic avian bone growth and healing. Vet. Clin. North. Am. Exot. Anim. Pract., v.5, p.23-30, 2002. 